\title{
Identification and evaluation of processes for joint disposal of high level radioactive waste and low to intermediate level radioactive waste
}

\author{
Andreas Poller ${ }^{1}$, Susie M. L. Hardie ${ }^{1}$, Gerhard Mayer ${ }^{1}$, Marie Pijorr $^{1}$, Joachim Poppei $^{1}$, Paul Smith $^{2}$, \\ Luca Urpi ${ }^{1}$, and Laurin Wissmeier ${ }^{1}$ \\ ${ }^{1}$ CSD Ingenieure AG, Aarau, Switzerland \\ ${ }^{2}$ Safety Assessment Management, Klingnau, Switzerland
}

Correspondence: Andreas Poller (a.poller@csd.ch)

Published: 10 November 2021

\begin{abstract}
The on-going research project „Identification and evaluation of processes that can arise by disposing of both high level radioactive waste (HAW) and low to intermediate level radioactive waste (LAW/MAW) at the same site" (GemEnd, FKZ 4719F10401), commissioned by the Federal Office for the Safety of Nuclear Waste Management (BASE), is concerned with the question which thermal, hydraulic, mechanical, chemical and biological (THMCB) processes could be of importance for the long-term safety of the geological repository for high level radioactive waste.

The focus of the project is on mutual influences between the HAW and LAW/MAW repositories, which should be constructed separately according to the Safety Regulations (Federal Ministry for the Environment, Nature Conservation and Nuclear Safety, BMU, 2020). A second point of emphasis is on processes that could result from the disposal of small amounts of LAW/MAW within the HAW repository.

The analyses carried out for each of the potential host rocks clay rock, rock salt and crystalline rock as well as for a combination of clay rock above crystalline rock at a generic site are divided into a qualitative and a quantitative part. As for the qualitative analyses, all potentially relevant processes are identified and evaluated as to whether they are negligible or principally relevant for the exemplary repository configurations considered and according to the current state of knowledge.

With regard to the quantitative analyses, the possible extent of potentially safety-relevant processes is illustrated by means of coupled numerical simulations. Of special interest are the effects of particularly sensitive model approaches and/or parameters and notably of the distances between the HAW and LAW/MAW repositories in the different exemplary repository configurations considered.

From the results of the quantitative and qualitative analyses, knowledge gaps will be identified and the possibility of their reduction by research and development activities will be discussed. Furthermore, aspects of the transferability of the results to the German site selection procedure will be illuminated.

At the interdisciplinary research symposium safeND selected preliminary results of both the qualitative and quantitative analyses will be presented.
\end{abstract}

Kurzfassung. Das laufende Forschungsvorhaben „Identifikation und Bewertung von Prozessen, die durch ein Endlager am gleichen Standort sowohl für hochradioaktive als auch für schwach- bis mittelradioaktive Abfälle entstehen können“ (GemEnd, FKZ 4719F10401) im Auftrag des Bundesamts für die Sicherheit der nuklearen Entsorgung (BASE) beschäftigt sich mit der Frage, welche thermischen, hydraulischen, mechanischen, chemischen und biologischen (THMCB) Prozesse für die Langzeitsicherheit des Endlagers für hochradioaktive Abfälle von Bedeutung sein können.

Im Fokus stehen dabei wechselseitige Beeinflussungen zwischen den HAW- und LAW/MAWEndlagerbergwerken, die gemäß Endlagersicherheitsanforderungsverordnung (BMU, 2020) getrennt aufzu- 
fahren sind. Ein weiterer Schwerpunkt liegt auf Prozessen, welche ggf. aus der Einlagerung von geringen Mengen an LAW/MAW innerhalb des HAW-Endlagerbergwerks resultieren.

Die durchgeführten Analysen, je für die Wirtsgesteine Tongestein, Steinsalz und Kristallingestein sowie eine Kombination mit überlagerndem Tongestein über Kristallingestein an einem generischen Standort, gliedern sich in einen qualitativen und einen quantitativen Teil. Im Rahmen der qualitativen Analyse werden alle potenziell relevanten Prozesse identifiziert und anschließend dahingehend bewertet, ob sie für die jeweils betrachtete exemplarische Endlagerkonfiguration nach heutigem Kenntnisstand im Hinblick auf die gemeinsame Endlagerung vernachlässigbar oder als grundsätzlich relevant einzustufen sind.

Im quantitativen Teil wird das mögliche Ausmaß von potenziell sicherheitsrelevanten Prozessen anhand von gekoppelten numerischen Modellrechnungen untersucht. Von besonderem Interesse sind hierbei die Auswirkungen besonders sensitiver Modellansätze und/oder Parameter und insbesondere der Einfluss des Abstandes zwischen den HAW- und LAW/MAW-Endlagerbergwerken.

Aus den Ergebnissen der qualitativen und quantitativen Analysen werden Kenntnisdefizite abgeleitet und die Möglichkeit ihrer Reduktion durch Forschungs- und Entwicklungsaktivitäten diskutiert. Weiter werden Aspekte der Übertragbarkeit der Ergebnisse auf das deutsche Standortauswahlverfahren beleuchtet.

Im Rahmen des interdisziplinären Forschungssymposiums safeND werden ausgewählte Zwischenergebnisse der qualitativen und quantitativen Analysen präsentiert.

\section{References}

BMU: Verordnung über Sicherheitsanforderungen und vorläufige Sicherheitsuntersuchungen für die Endlagerung hochradioaktiver Abfälle, BMU, 2020, online aufrufbar: http://www.bgbl.de/xaver/bgbl/start.xav?startbk= Bundesanzeiger_BGB1\&jumpTo=bgbl120s2094.pdf (letzter Zugriff: 18, Oktober 2021), 2020. 